犊

Global Journals Inc.

(c)

GLOBAL JOURNAL OF RESEARCHES IN ENGINEERING: E

CIVIL AND STRUCTURAL ENGINEERING

Volume 20 Issue 3 Version 1.0 Year 2020

Type: Double Blind Peer Reviewed International Research Journal

\title{
Causes of Delays in Road Construction Projects in Laos
}

\section{By Bounthipphasert Soumphonphakdy, Shozo Nakamura, Toshihiro Okumatsu \& Takafumi Nishikawa}

Abstract- One of the most important sectors in infrastructure development in Laos is road construction. However, many road construction projects in Laos suffer from extensive delays. This causes damage such as recurring problems in the road construction industry, and has a negative effect on the success of road construction projects in terms of schedule, cost, quality, safety and the amenity of road users. The goal of this study is to determine the main causes of these delays and to offer remedies. To identify the causes of delays, a questionnaire is designed by modifying one used to measure causes of delays in road construction projects in the West Bank in Palestine and in consultation with engineering experts with more than 10 years of experience in Laos road construction projects. A total of 53 causes of delay are identified as important in Laos. Questionnaire respondents included 35 contractors, 31 owners and 24 consultants in total. The survey results indicate that the five top factors causing road construction delays are: Contractor cash flow; Delayed payment by owner; Difficulties in financing project by contractor; Financial issues related to owner; and Insufficient equipment and vehicles for the work.

Keywords: causes of delay; road construction projects; severity index; laos.

GJRE-E Classification: FOR Code: 090502

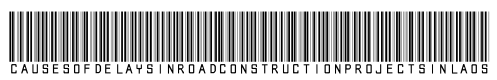

Strictly as per the compliance and regulations of:

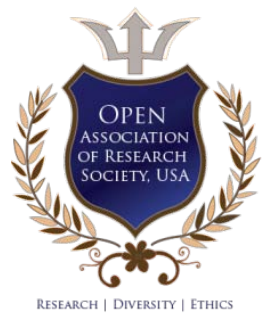

(C) 2020. Bounthipphasert Soumphonphakdy, Shozo Nakamura, Toshihiro Okumatsu \& Takafumi Nishikawa. This is a research/review paper, distributed under the terms of the Creative Commons Attribution-Noncommercial 3.0 Unported License http://creativecommons.org/licenses/by-nc/3.0/), permitting all non-commercial use, distribution, and reproduction in any medium, provided the original work is properly cited. 


\title{
Causes of Delays in Road Construction Projects
} in Laos

\author{
Bounthipphasert Soumphonphakdy ${ }^{\alpha}$, Shozo Nakamura $^{\sigma}$, Toshihiro Okumatsu $^{\circ}$ \& Takafumi Nishikawa $^{\omega}$
}

Abstract- One of the most important sectors in infrastructure development in Laos is road construction. However, many road construction projects in Laos suffer from extensive delays. This causes damage such as recurring problems in the road construction industry, and has a negative effect on the success of road construction projects in terms of schedule, cost, quality, safety and the amenity of road users. The goal of this study is to determine the main causes of these delays and to offer remedies. To identify the causes of delays, a questionnaire is designed by modifying one used to measure causes of delays in road construction projects in the West Bank in Palestine and in consultation with engineering experts with more than 10 years of experience in Laos road construction projects. A total of 53 causes of delay are identified as important in Laos. Questionnaire respondents included 35 contractors, 31 owners and 24 consultants in total. The survey results indicate that the five top factors causing road construction delays are: Contractor cash flow; Delayed payment by owner; Difficulties in financing project by contractor; Financial issues related to owner; and Insufficient equipment and vehicles for the work.

Keywords: causes of delay; road construction projects; severity index; laos.

\section{INTRODUCTION}

\section{L} aos is a landlocked developing country located in the heart of the Indochina Peninsular. It shares borders with five other countries (namely China, Myanmar, Thailand, Vietnam and Cambodia). Based on its strategic location, Laos has the potential to transform itself into a land-linked country developing connections with its neighbors through the road network and railways. Thus, development of the transportation infrastructure is one of the most important means of promoting the country's economic development. In the decades since independence in 1975, the Lao Government has invested significantly in infrastructure development, especially expanding and improving the road network.

The total length of the road network in Laos is over $60,340 \mathrm{~km}$, including $552 \mathrm{~km}$ of reinforced concrete $(\mathrm{RC})$ roads, 1,203 $\mathrm{km}$ of asphalt concrete (AC), 9,973

Author a: Graduate School of Engineering, Nagasaki University, 1-14, Bunkyo-machi, Nagasaki 852-8521, Japan.

e-mail: soumphonphakdy_1011@yahoo.co.jp

Author $\sigma:$ Department of Civil and Environmental Engineering, Nagasaki University, 1-14, Bunkyo-machi, Nagasaki 852-8521, Japan.

e-mail:shozo@nagasaki-u.ac.jp

Author $\rho$ w: Department of Civil and Environmental Engineering, Nagasaki University, 1-14, Bunkyo-machi, Nagasaki 852-8521, Japan. $\mathrm{km}$ of double bituminous surface treatment (DBST), $23,179 \mathrm{~km}$ of gravel and $25,433 \mathrm{~km}$ non-paved. There is still a lack of annual budgets for road maintenance, rehabilitation and upgrading to ensure standards and improved road safety.

As in many countries, road construction projects often fall behind schedule in Laos. In fact, 36 of 59 ongoing projects in January 2020 had been behind schedule. This is an important issue affecting the management of road construction projects. There is a need to study the main causes of such delays and search for solutions that improve the situation. Delays in road construction have many negative impacts, such as budget over-runs and effects on the economy, the environment and other areas. They particularly affect those who use the roads and/or live near roads under construction, both directly and indirectly. The causes of road construction delays vary by country. Thus, it is important to determine the main common causes of delay in road construction projects in Laos.

In this study, a questionnaire survey was carried out. The questionnaire was designed by modifying one used to measure causes of delays in road construction projects in the West Bank in Palestine [1] and in consultation with engineering experts with more than 10 years of experience in Laos road construction projects, and sent to contractors, owners and consultants.

The main objectives of this study are the following:

- To identify the causes of delays in road construction projects in Laos;

- To rank the causes of delays in road construction projects in Laos;

- To identify the severity of delay causes from the perspective of contractors, owners and consultants;

- To test agreement on the ranking of the severity of delay causes among contractors, owners and consultants;

- To find ways to eliminate the causes of delays in road construction projects in Laos;

- To provide this research data to owners, consultants, contractors and designers for use in preparing and planning road construction; and

- To provide knowledge for engineers and the general public interested in the analysis of factors that cause problems due to delays in road construction projects in Laos. 


\section{LiteratURE REVIEW}

Many articles have reported studies on the causes of delay in construction projects. For example, Mahamid et al. [1] found that there are 52 possible causes of delay in road construction projects. Among these, 18 had a severity index (see eq. (1)) of over 60\%, indicating a high or very high impact. A.M. Odeh and H.T. Battaomeh [2] used a survey to study the delays arising in construction projects with traditional contracts from the viewpoint of construction contractors and consultants. Results indicated that there was agreement among contractors and consultants that owner interference, inadequate contractor experience, financing and payments, labor productivity, slow decision making, improper planning, and subcontractors are among the top ten most important factors. Y. Frimpong et al. [3] found that delays and cost overruns are common in construction projects and groundwater development projects in Ghana. Their survey included personnel from owners, consultants and contractors involved in groundwater-related projects. The main causes of delays and cost overruns included difficulty in obtaining monthly payments from agencies; poor contract management; material procurement; poor technical performance; and material price inflation. The study concluded that effective project planning, control and monitoring should be established to enhance project performance in order to minimize or avoid delays and cost problems in groundwater-related projects. J.A. Alsuliman [4] investigated the causes of delays in Saudi public construction projects and categorized them based on the various stages of a project, namely (1) factors before the award of tenders, (2) factors during the award of tenders, (3) factors after the award of tenders, and (4) general factors. Through the use of a focus group, this study identified 50 delay factors. A questionnaire was administered and distributed to 211 people involved in the construction industry. From the results, the top 20 causes of delay were identified. A final simplified formula was developed to calculate the effect of each cause of delay on site. A case study was carried out to determine the percent time delay compared with the master schedule using the developed simpfied formula. Banobi E.T.B. and W. Jung [5] investigated 82 owner-side experts and 106 contractor-side experts in Tanzanian power construction projects. In successful projects (less than 10\% time delay), the owners and contractors gave weight to similar causes, including vandalism and permits from authorities. Both suggested similar mitigation strategies such as close supervision, capacity building training, and proper logistics management. On the other hand, in the case of unsuccessful projects (more than 10\% time delay), they exhibited many different responses. In particular, contractors gave more weight than contractors to causes such as changes in scope, poor supervision by the owner, delays in approval, planning failures, and design risks. Owners on the other hand gave more weight to mitigation strategies such as top management support and timely procurement. R.F. Aziz and A.A. Abdel-Hakam [6] investigated strategies to effectively overcome road construction delays in developing countries, concluding with suggestions for fundamental and large-scale reform of procurement systems and stakeholder management. Khatib, B.A., Poh, Y.S. and El-Shafie [7] conducted fourteen interviews with project managers, construction managers, and senior site engineers to identify the factors they faced that led to delays in a reconstruction project. The identified factors were divided into two groups: one related to the demolition phase (five factors) and the second related to reconstruction work (nine factors). The supply of building materials during the reconstruction phase was considered one of the major delaying factors and 14 delay factors were identified that should be carefully considered to assure the sustainability of the main objective during reconstruction activities. A. Orangi et al. [8] found that delays could lead to some serious time and/or cost overrun issues, thereby adversely affecting contractors, clients and other stakeholders to different degrees. They concluded that consolidating knowledge from related research and lessons from recent projects would be beneficial for rationalized project management. In particular, identifying significant root causes of delays and then developing suitable management methods (e.g. prevention measures) are essential to effectively ensuring successful project outcomes.

M.H. Fallahnejad [9] set out to identify and rank the causes of delays in gas pipeline projects in Iran. 24 completed gas pipeline projects were studied and the extracted delay factors were discussed with 10 experts from several disciplines. The result was a 43-item list of factors, which were then ranked by means of a questionnaire survey. The 10 major delay factors were found to be the following: imported materials, unrealistic project timescale, client-related materials, land expropriation, change orders, contractor selection methods, payments to contractor, obtaining permits, suppliers, and contractor's cash flow". Majed Alxara et al. [10] studied the issues faced by Saudi Arabia in completing construction projects on time and on budget. It has been documented that $70 \%$ of public construction projects are delayed in the country. A case study was performed at a university campus in northern Saudi Arabia, identifying the major causes of project delays. The university had experienced delays ranging from $50 \%$ to $150 \%$. The study proposed solutions for minimizing the nine major delay factors. A literature research identified one construction management method, the Performance Information Procurement System (PIPS), that has been documented multiple times to improve project performance and minimize 
delays. B.-G. Hwang et al. [11] looked at reducing wait times for future public housing owners, which requires such projects to be completed on time. A survey of 36 industry experts revealed that "site management", "coordination among various parties", and "availability of laborers on site" were the top three factors affecting the schedule performance of public housing projects in Singapore. In findings from a case study, Raj Shah [12] clarified that the most influential factors in Australia are (1) planning and scheduling deficiencies, (2) methods of construction, (3) effective monitoring and feedback processes, which contrasts with Ghana where they were (1) delays in payment certificates (2) underestimating of project cost, (3) project complexity. On the other hand, in Malaysia the most influential factors are (1) improper planning by contractors, (2) poor site management, and (3) inadequate contractor experience. It is clear that the factors causing project delays and cost overruns are diverse and vary from one country to another. N.D. Long et al. [13] presented problems with large construction projects in Vietnam. Data analysis revealed that the problems could be grouped underfive major headings:

(1) incompetent designers/contractors, (2) poor estimation and change management, (3) social and technological issues, (4) site related issues, and (5) improper techniques and tools. Michałuszak and Agnieszka Leśniak [14] carried out a survey and multivariate statistical analysis of client's ideas about construction delays in Poland. They found that timely implementation of construction work (at the scheduled time) is vital for both the investor and the contractor. Even perfectly planned and organized projects run the risk of delays. Despite many tools supporting construction management, delays keep occurring in construction projects. S.O. Ogun Lana et al. [15] took the view that construction industry problems in developing economies can be nested in three layers: (a) problems of shortages or inadequacies in industry infrastructure (mainly supply of resources); (b) problems caused by clients and consultants and (c) problems caused by contractor incompetence/inadequacies.

\section{ili. Research Methodology}

\section{a) Questionnaire Design}

In this paper, based on work in the literature [1], a questionnaire was developed in consultation with civil engineers who had more than 10 years of experience in road construction projects in Laos. Final modifications were made to accommodate the whole range of information about effective causes of delay in road construction projects in Laos. A total of 53 possible causes were included in the questionnaire.

In terms of structure, the questionnaire was designed to have two main parts. Part I is related to respondents' personal information, including whether they are contractors, owners or consultants. It includes questions pertaining to their experience in the construction industry. Part II includes the list of the identified causes of delay in road construction projects in Laos. These causes are classified into eight main groups as shown in Table 1 according to the source of delay: project, owner, contractor, consultant, design, laborers, materials and equipment, and external. For each cause a question was asked about its degree of severity in terms of contributing to project delay. Severity was categorized into six-levels as follows: level $0=$ no influence; level 1 = very low; level 2 =low; level $3=$ moderate; level $4=$ high; and level $5=$ very high.

Table 1: List of Possible Delay Causes and Groupings

\begin{tabular}{c|ll}
\hline Main group & \multicolumn{2}{|l}{ Causes under each group } \\
\hline \multirow{3}{*}{ 1. Project group } & 1 & Low project bid price \\
2 & 3 & Construction area restricted \\
4 & Inconvenient site access \\
& 5 & Poor ground conditions \\
& 6 & Poor terrain conditions \\
\hline \multirow{5}{*}{ 2. Owner group } & 7 & Delayed payment by owner \\
& 8 & Delayed decision by owner \\
& 9 & Coordination between owner and contractor. \\
& 10 & Unreasonable project timeframe \\
& 11 & Financial issues related to owner \\
12 & Project delayed by owner \\
& 13 & Delayed approval of materials \\
& 14 & Not well-defined scope of work \\
& 15 & Delayed land expropriation by owner \\
16 & Change order from owner during construction \\
17 & Late issue of approval documents by owner. \\
& 18 & Unclear assignment of responsibility near province boundaries \\
\hline
\end{tabular}




\begin{tabular}{|c|c|c|}
\hline 3. Contractor group & $\begin{array}{l}19 \\
20 \\
21 \\
22 \\
23 \\
24 \\
25 \\
26 \\
27 \\
28 \\
29\end{array}$ & $\begin{array}{l}\text { Difficulties in financing project by contractor } \\
\text { Poor communication between contractor and other parties } \\
\text { Conflict between contractor and other parties } \\
\text { Poor resource management } \\
\text { Necessity to re-do work due to contractor failings } \\
\text { Ineffective planning management by contractor } \\
\text { Insufficiently skilled technical staff } \\
\text { Insufficient equipment and vehicles for the work } \\
\text { Poor quality control } \\
\text { Improper construction method } \\
\text { Contractor cash flow }\end{array}$ \\
\hline 4. Consultant group & $\begin{array}{l}30 \\
31 \\
32 \\
33 \\
34\end{array}$ & $\begin{array}{l}\text { Consultant too lenient } \\
\text { Poor coordination between the consultant and contractor(s) } \\
\text { Delay in implementing inspection by consultant } \\
\text { Poorly qualified inspector } \\
\text { Insufficient inspectors }\end{array}$ \\
\hline 5. Design group & $\begin{array}{l}35 \\
36 \\
37 \\
\end{array}$ & $\begin{array}{l}\text { Delayed design work } \\
\text { Mistakes in design } \\
\text { Inappropriate design }\end{array}$ \\
\hline 6. Laborers group & $\begin{array}{l}38 \\
39 \\
40 \\
41 \\
42\end{array}$ & $\begin{array}{l}\text { Low labor productivity } \\
\text { Insufficiently skilled equipment operator } \\
\text { Insufficient laborers } \\
\text { Personal conflict between laborers and management team } \\
\text { Personal conflict among laborers }\end{array}$ \\
\hline $\begin{array}{l}\text { 7. Materials and } \\
\text { equipment group }\end{array}$ & $\begin{array}{l}43 \\
44 \\
45 \\
46\end{array}$ & $\begin{array}{l}\text { Lack of equipment efficiency } \\
\text { Shortage of equipment } \\
\text { Changes in material types and specifications during construction } \\
\text { Shortage in materials }\end{array}$ \\
\hline 8. External group & $\begin{array}{l}47 \\
48 \\
49 \\
50 \\
51 \\
52 \\
53\end{array}$ & $\begin{array}{l}\text { Political situation } \\
\text { Exchange rate fluctuation under contract } \\
\text { Change in loans policy by bank } \\
\text { Weather conditions } \\
\text { Monopoly market } \\
\text { Oil price increase } \\
\text { Public events }\end{array}$ \\
\hline
\end{tabular}

\section{b) Data Analysis}

\section{i. Ranking of Delay Causes}

The suggested delay causes were ranked by severity index. The following formula was used to rank them on the basis of impact level as identified by the participants:

$$
\begin{aligned}
& \text { Severity } \\
& \text { index (\%) }
\end{aligned}=\sum a(n / N) * 100 / 5
$$

where $\mathrm{a}=$ severity level, which ranges from 0 for no influence up to 5 for very high, $\mathrm{n}=$ frequency of response and $\mathrm{N}=$ total number of responses.
Accordingly, if all participants respond that a particular cause has no influence, then that cause gains a severity index of 0 , meaning that it is not relevant to project delays and ranks last. Conversely, if all respond that it has a very high influence, then the severity index is 100 , meaning that this cause is very highly relevant and is the first in rank. Table 2 shows the possible ranges for the severity index and the corresponding impact level.

Table 2: Severity Index and Corresponding Impact Level

\begin{tabular}{cc}
\hline Severity index (\%) & Impact level \\
\hline 0 & No influence \\
\hline $0-20$ & Very low \\
\hline $20-40$ & Low \\
\hline $40-60$ & Moderate \\
\hline $60-80$ & High \\
\hline $80-100$ & Very high \\
\hline
\end{tabular}

The severity index for each cause was calculated according to Eq. (1) from the individual contractors', owners' and consultants' responses as well as from the combined responses. 
A group index was calculated by using the average of the severity indexes of the causes in each group such that

$$
\begin{aligned}
& \text { Group } \\
& \text { severity } \\
& \text { index (\%) }
\end{aligned} \quad=\sum_{i=1}^{n} X_{i} / n
$$

where $\mathrm{X} i=$ severity index of cause $\mathrm{i}$ in the group and $\mathrm{n}$ $=$ number of causes in the group.

\section{ii. Rank Correlation}

The Spearman rank correlation was used to measure the correspondence between pairs of rankings in the sample observations, thereby comparing how well the contractors, owners and consultants agree on the causes of delay. A perfect positive correlation $\left(r_{\mathrm{s}}=+1\right)$ indicates that the object is ranked identically in the compared samples, whereas a perfect negative correlation $\left(r_{s}=-1\right)$ indicates that the rankings have an exactly inverse relationship. This means that sample correlations close to unity in magnitude imply a good correlation, whereas values near 0 indicate low or no correlation. The Spearman rank correlation formula is as follows:

$$
r_{s}=1-\left[6 * \sum d^{2} /\left(n^{3}-n\right)\right]
$$

Where $r s=$ Spearman rank correlation coefficient between two parties, $d=$ difference between ranks assigned to variables for each cause and $n=$ number of pairs of rankings.

\section{Results And Discussions}

\section{a) Respondent Personal Information}

The questionnaire was sent to a total of 50 contractors, 40 owners and 30 consultants. A total of 35 contractors (70.0\%), 31 owners (77.5\%) and 24 consultants (80.0\%) completed the questionnaire as shown in Table 3. All of the respondents were engineers. Among them, 30 had between 5 and 10 years of experience, 18 had 10 to 15 years of experience and 42 had over 15 years of experience. The average was approximately 16 years' experience.

Table 3: List of Responses (percent)

\begin{tabular}{cccc}
\hline Respondents & $\begin{array}{c}\text { Questionnaire } \\
\text { distributed }\end{array}$ & $\begin{array}{c}\text { Responses } \\
\text { returned }\end{array}$ & $\begin{array}{c}\text { Percentage of } \\
\text { responses }\end{array}$ \\
\hline Contractors & 50 & 35 & $70.0 \%$ \\
Owners & 40 & 31 & $77.5 \%$ \\
Consultants & 30 & 24 & $80.0 \%$ \\
\hline Total & 120 & 90 & $75.0 \%$ \\
\hline
\end{tabular}

\section{b) Ranking of Delay Causes by Group}

\section{i. Project Group}

Six delay causes are listed in this group. Table 4 shows the severity index and ranking of each one from the viewpoint of contractors, owners and consultants, as well as the combined viewpoint (the combination of contractor, owner and consultant views). It is clear that the most severe cause of delays from the combined viewpoint is "Low project bid price". However, the rankings from the individual viewpoints are quite different.

The results also show that the difference between the most and least severe causes in this group is $37.22 \%$.

\begin{tabular}{|c|c|c|c|c|c|c|c|c|}
\hline \multirow[b]{2}{*}{ Cause } & \multicolumn{2}{|c|}{ Combined' view } & \multicolumn{2}{|c|}{ Contractors' view } & \multicolumn{2}{|c|}{ Owners' view } & \multicolumn{2}{|c|}{ Consultants' view } \\
\hline & $\begin{array}{c}\text { Severity } \\
\text { index } \\
(\%)\end{array}$ & Rank & $\begin{array}{c}\text { Severity } \\
\text { index } \\
(\%)\end{array}$ & Rank & $\begin{array}{c}\text { Severity } \\
\text { index } \\
(\%)\end{array}$ & Rank & $\begin{array}{c}\text { Severity } \\
\text { index } \\
(\%)\end{array}$ & Rank \\
\hline Low project bid price & 60.00 & 1 & 76.57 & 1 & 39.35 & 5 & 62.50 & 1 \\
\hline Poor soil quality & 46.89 & 2 & 43.43 & 6 & 47.10 & 1 & 51.67 & 2 \\
\hline Poor terrain conditions & 46.22 & 3 & 48.00 & 4 & 45.81 & 2 & 44.17 & 3 \\
\hline Poor ground conditions & 45.11 & 4 & 47.43 & 5 & 45.81 & 2 & 40.83 & 4 \\
\hline $\begin{array}{c}\text { Inconvenient site } \\
\text { access }\end{array}$ & 43.78 & 5 & 50.86 & 2 & 40.65 & 4 & 37.50 & 6 \\
\hline $\begin{array}{l}\text { Construction area } \\
\text { restricted }\end{array}$ & 42.67 & 6 & 49.14 & 3 & 38.71 & 6 & 38.33 & 5 \\
\hline
\end{tabular}

Table 4: Ranking of Delay Causes in Project Group

ii. Owner Group

This group includes twelve causes. Table 5 presents the rankings from each viewpoint, showing that the most severe cause from all viewpoints is "Delayed payment by owner".
The most severe causes in the rankings by contractors, owners, consultants and the combined view are quite similar, with 1 to 3 in the rankings being "Delayed payment by owner", "Financial issues related to owner" and "Delayed decision by owner", 
respectively, except in the case of owners and consultants.

The results also indicate that the most severe causes in this group are quite distinct. In the combined view, for example, there is a wide span of severity ranging from $38.00 \%$ to $81.56 \%$, a difference of $43.56 \%$. That is, the causes range from low to very high severity and the difference in its severity index.

Table 5: Ranking of Delay Causes in Owner Group

\begin{tabular}{|c|c|c|c|c|c|c|c|c|}
\hline \multirow[b]{2}{*}{ Cause } & \multicolumn{2}{|c|}{ Combined' view } & \multicolumn{2}{|c|}{ Contractors' view } & \multicolumn{2}{|c|}{ Owners' view } & \multicolumn{2}{|c|}{$\begin{array}{c}\text { Consultants' } \\
\text { view }\end{array}$} \\
\hline & $\begin{array}{c}\text { Severity } \\
\text { index } \\
(\%)\end{array}$ & Rank & $\begin{array}{c}\text { Severity } \\
\text { index } \\
(\%)\end{array}$ & Rank & $\begin{array}{c}\text { Severity } \\
\text { index } \\
(\%)\end{array}$ & Rank & $\begin{array}{c}\text { Severity } \\
\text { index } \\
(\%)\end{array}$ & Rank \\
\hline Delayed payment by owner & 81.56 & 1 & 91.43 & 1 & 73.55 & 1 & 77.50 & 1 \\
\hline $\begin{array}{c}\text { Financial issues related to } \\
\text { owner }\end{array}$ & 75.11 & 2 & 85.71 & 2 & 68.39 & 2 & 68.33 & 2 \\
\hline Delayed decision by owner & 57.33 & 3 & 71.43 & 3 & 48.39 & 4 & 48.33 & 4 \\
\hline $\begin{array}{l}\text { Change order from owner } \\
\text { during construction }\end{array}$ & 51.33 & 4 & 57.71 & 8 & 45.81 & 5 & 49.17 & 3 \\
\hline $\begin{array}{l}\text { Coordination between owner } \\
\text { and contractor. }\end{array}$ & 49.78 & 5 & 60.00 & 6 & 43.87 & 6 & 42.50 & 8 \\
\hline $\begin{array}{l}\text { Late issue of approval } \\
\text { documents by owner. }\end{array}$ & 49.56 & 6 & 61.14 & 5 & 40.65 & 8 & 44.17 & 6 \\
\hline $\begin{array}{l}\text { Unreasonable project } \\
\text { timeframe }\end{array}$ & 49.33 & 7 & 50.86 & 10 & 52.26 & 3 & 43.33 & 7 \\
\hline Not well-defined scope of work & 48.00 & 8 & 58.86 & 7 & 41.94 & 7 & 40.00 & 11 \\
\hline $\begin{array}{c}\text { Delayed land expropriation by } \\
\text { owner }\end{array}$ & 47.11 & 9 & 53.14 & 9 & 40.65 & 8 & 46.67 & 5 \\
\hline Delayed approval of materials & 46.89 & 10 & 63.43 & 4 & 37.42 & 10 & 35.00 & 12 \\
\hline $\begin{array}{l}\text { Project delayed by owner } \\
\text { Unclear assignment of }\end{array}$ & 41.33 & 11 & 48.00 & 11 & 32.90 & 11 & 42.50 & 8 \\
\hline $\begin{array}{c}\text { responsibility near province } \\
\text { boundaries }\end{array}$ & 38.00 & 12 & 44.57 & 12 & 28.39 & 12 & 40.83 & 10 \\
\hline
\end{tabular}

iii. Contractors Group

There are eleven causes in the contractors group. Table 6 shows that the cause with the highest severity from the combined, contractors', owners' and consultants' views is "Contractor cash flow". The top and second ranked causes from all viewpoints are quite similar. In the combined view, the range of severity for all causes is narrow, ranging from $46.22 \%$ to $84.22 \%$, meaning that the effect on delays is moderate to very high.

Table 6: Ranking of Delay Causes in Contractor Group

\begin{tabular}{|c|c|c|c|c|c|c|c|c|}
\hline \multirow[b]{2}{*}{ Cause } & \multicolumn{2}{|c|}{ Combined' view } & \multicolumn{2}{|c|}{ Contractors' view } & \multicolumn{2}{|c|}{ Owners' view } & \multicolumn{2}{|c|}{ Consultants' view } \\
\hline & $\begin{array}{c}\text { Severity } \\
\text { index } \\
(\%)\end{array}$ & Rank & $\begin{array}{c}\text { Severity } \\
\text { index } \\
(\%)\end{array}$ & Rank & $\begin{array}{c}\text { Severity } \\
\text { index } \\
(\%)\end{array}$ & Rank & $\begin{array}{c}\text { Severity } \\
\text { index } \\
(\%)\end{array}$ & Rank \\
\hline Contractor cash flow & 84.22 & 1 & 88.00 & 1 & 78.71 & 1 & 85.83 & 1 \\
\hline $\begin{array}{l}\text { Difficulties in financing project by } \\
\text { contractor }\end{array}$ & 77.11 & 2 & 82.29 & 2 & 75.48 & 2 & 71.67 & 3 \\
\hline $\begin{array}{l}\text { Insufficient equipment and } \\
\text { vehicles for the work }\end{array}$ & 70.89 & 3 & 77.71 & 3 & 61.29 & 3 & 73.33 & 2 \\
\hline Poor quality control & 63.11 & 4 & 71.43 & 4 & 54.19 & 6 & 62.50 & 5 \\
\hline Insufficiently skilled technical staff & 59.78 & 5 & 61.14 & 5 & 57.42 & 4 & 60.83 & 6 \\
\hline $\begin{array}{l}\text { Ineffective planning management } \\
\text { by contractor }\end{array}$ & 57.33 & 6 & 52.00 & 7 & 57.42 & 4 & 65.00 & 4 \\
\hline Improper construction method & 56.00 & 7 & 58.29 & 6 & 49.68 & 8 & 60.83 & 6 \\
\hline $\begin{array}{l}\text { Poor communication between } \\
\text { contractor and other parties }\end{array}$ & 52.00 & 8 & 49.71 & 9 & 52.90 & 7 & 54.17 & 8 \\
\hline $\begin{array}{l}\text { Necessity to re-do work due to } \\
\text { contractor failings }\end{array}$ & 49.78 & 9 & 50.29 & 8 & 46.45 & 10 & 53.33 & 9 \\
\hline Poor resource management & 46.44 & 10 & 49.71 & 10 & 41.94 & 11 & 47.50 & 11 \\
\hline $\begin{array}{c}\text { Conflict between contractor and } \\
\text { other parties }\end{array}$ & 46.22 & 11 & 42.86 & 11 & 47.74 & 9 & 49.17 & 10 \\
\hline
\end{tabular}


iv. Consultant Group

Table 7 shows the severity index and ranking of each cause under the consultants group. five causes are identified under this group.

Table 7 shows the results that the most severe cause from the combined view, owners' view and consultants' view is "Insufficient inspectors". It is clear from the results that the severity index ranking from the combined view has a narrow span, with severity indexes ranging from $41.33 \%$ to $52.00 \%$. That is, all causes in this group have a moderate effect on road construction project delays.

Table 7: Ranking of Delay Causes in Consultant Group

\begin{tabular}{|c|c|c|c|c|c|c|c|c|}
\hline \multirow[b]{2}{*}{ Cause } & \multicolumn{2}{|c|}{ Combined' view } & \multicolumn{2}{|c|}{$\begin{array}{c}\text { Contractors' } \\
\text { view }\end{array}$} & \multicolumn{2}{|c|}{ Owners' view } & \multicolumn{2}{|c|}{$\begin{array}{c}\text { Consultants' } \\
\text { view }\end{array}$} \\
\hline & $\begin{array}{c}\text { Severity } \\
\text { index } \\
(\%) \\
\end{array}$ & Rank & $\begin{array}{l}\text { Severity } \\
\text { index } \\
(\%) \\
\end{array}$ & Rank & $\begin{array}{c}\text { Severity } \\
\text { index } \\
(\%)\end{array}$ & Rank & $\begin{array}{l}\text { Severity } \\
\text { index } \\
(\%) \\
\end{array}$ & Rank \\
\hline Insufficient inspectors & 52.00 & 1 & 68.00 & 2 & 43.23 & 1 & 40.00 & 1 \\
\hline $\begin{array}{l}\text { Delay in implementing } \\
\text { inspection by consultant } \\
\text { Poor coordination }\end{array}$ & 50.44 & 2 & 70.86 & 1 & 39.35 & 4 & 35.00 & 3 \\
\hline $\begin{array}{l}\text { between the consultant } \\
\text { and contractor(s) }\end{array}$ & 47.78 & 3 & 61.71 & 4 & 40.65 & 2 & 36.67 & 2 \\
\hline Poorly qualified inspector & 47.78 & 3 & 65.71 & 3 & 38.71 & 5 & 33.33 & 4 \\
\hline Consultant too lenient & 41.33 & 5 & 52.00 & 5 & 40.65 & 2 & 26.67 & 5 \\
\hline
\end{tabular}

v. Design Group

Table 8 shows the severity index and ranking of each cause in the design group. The most severe of the three causes in this group is "Delayed design work" for all viewpoints. The rankings from the contractors', owners', consultants' and combined views are all similar. The span of severity values in the combined view is quite narrow, ranging from $44.22 \%$ to $48.22 \%$. That is, all causes in this group have a moderate effect on road construction project delays.

Table 8: Ranking of Delay Causes in Design Group

\begin{tabular}{|c|c|c|c|c|c|c|c|c|}
\hline \multirow[b]{2}{*}{ Cause } & \multicolumn{2}{|c|}{ Combined' view } & \multicolumn{2}{|c|}{ Contractors' view } & \multicolumn{2}{|c|}{ Owners' view } & \multicolumn{2}{|c|}{ Consultants' view } \\
\hline & $\begin{array}{c}\text { Severity } \\
\text { index } \\
(\%)\end{array}$ & Rank & $\begin{array}{c}\text { Severity } \\
\text { index } \\
(\%) \\
\end{array}$ & Rank & $\begin{array}{c}\text { Severity } \\
\text { index } \\
(\%)\end{array}$ & Rank & $\begin{array}{c}\text { Severity } \\
\text { index } \\
(\%)\end{array}$ & Rank \\
\hline $\begin{array}{c}\text { Delayed design } \\
\text { work }\end{array}$ & 48.22 & 1 & 46.29 & 1 & 47.74 & 1 & 51.67 & 1 \\
\hline Mistakes in design & 46.22 & 2 & 44.57 & 2 & 45.16 & 2 & 50.00 & 2 \\
\hline $\begin{array}{l}\text { Inappropriate } \\
\text { desian }\end{array}$ & 44.22 & 3 & 44.57 & 3 & 44.52 & 3 & 43.33 & 3 \\
\hline
\end{tabular}

vi. Laborers Group

Table 9 shows the severity index and ranking of each cause in the laborers group. Five causes are identified in this group. All viewpoints except owners find that "Insufficient laborers" is the most severed delay cause; this ranks second for owners.
All of the rankings in Table 9 are quite similar. The severity index from the combined view ranges from $39.78 \%$ to $63.33 \%$, meaning that these delay causes have an impact ranging from low to high.

Table 9: Ranking of Delay Causes in Laborers Group

\begin{tabular}{|c|c|c|c|c|c|c|c|c|}
\hline \multirow[b]{2}{*}{ Cause } & \multicolumn{2}{|c|}{ Combined' view } & \multicolumn{2}{|c|}{ Contractors' view } & \multicolumn{2}{|c|}{ Owners' view } & \multicolumn{2}{|c|}{ Consultants' view } \\
\hline & $\begin{array}{l}\text { Severity } \\
\text { index } \\
(\%)\end{array}$ & Rank & $\begin{array}{l}\text { Severity } \\
\text { index } \\
(\%)\end{array}$ & Rank & $\begin{array}{l}\text { Severity } \\
\text { index } \\
(\%)\end{array}$ & Rank & $\begin{array}{l}\text { Severity } \\
\text { index } \\
(\%)\end{array}$ & Rank \\
\hline Insufficient laborers & 63.33 & 1 & 68.57 & 1 & 50.97 & 2 & 71.67 & 1 \\
\hline $\begin{array}{c}\text { Insufficiently skilled equipment } \\
\text { operator }\end{array}$ & 61.33 & 2 & 68.57 & 2 & 52.90 & 1 & 61.67 & 2 \\
\hline Low labor productivity & 58.22 & 3 & 68.00 & 3 & 50.97 & 2 & 53.33 & 3 \\
\hline $\begin{array}{c}\text { Personal conflict between } \\
\text { laborers and management } \\
\text { team }\end{array}$ & 43.11 & 4 & 44.00 & 4 & 41.94 & 4 & 43.33 & 4 \\
\hline $\begin{array}{c}\text { Personal conflict among } \\
\text { laborers }\end{array}$ & 39.78 & 5 & 40.00 & 5 & 36.77 & 5 & 43.33 & 4 \\
\hline
\end{tabular}




\section{vii. Materials and Equipment Group}

The material and equipment group comprises four delay causes. Table 10 shows that the most severe cause in the combined view is "Lack of equipment efficiency". The rankings from the contractors', owners' and combined views are quite similar, while consultants rank "Lack of equipment efficiency" third. However, first, second and third most severe causes are all grouped together.

The range of severity index values from the combined view is narrow, with values from $55.11 \%$ to $65.33 \%$. That is, their impact on project delays ranges from moderate to high.

Table 10: Ranking of Delay Causes in Materials and equipment Group

\begin{tabular}{|c|c|c|c|c|c|c|c|c|}
\hline \multirow[b]{2}{*}{ Cause } & \multicolumn{2}{|c|}{$\begin{array}{c}\text { Combined' } \\
\text { view }\end{array}$} & \multicolumn{2}{|c|}{$\begin{array}{c}\text { Contractors' } \\
\text { view }\end{array}$} & \multicolumn{2}{|c|}{ Owners' view } & \multicolumn{2}{|c|}{$\begin{array}{c}\text { Consultants' } \\
\text { view }\end{array}$} \\
\hline & $\begin{array}{c}\text { Severity } \\
\text { index } \\
(\%)\end{array}$ & Rank & $\begin{array}{c}\text { Severity } \\
\text { index } \\
(\%)\end{array}$ & Rank & $\begin{array}{c}\text { Severity } \\
\text { index } \\
(\%)\end{array}$ & Rank & $\begin{array}{c}\text { Severity } \\
\text { index } \\
(\%)\end{array}$ & Rank \\
\hline Lack of equipment efficiency & 65.33 & 1 & 74.86 & 2 & 56.77 & 1 & 62.50 & 3 \\
\hline Shortage of equipment & 65.11 & 2 & 75.43 & 1 & 52.26 & 2 & 66.67 & 1 \\
\hline Shortage in materials & 58.22 & 3 & 61.71 & 3 & 48.39 & 3 & 65.83 & 2 \\
\hline $\begin{array}{l}\text { Changes in material types and } \\
\text { specifications during construction }\end{array}$ & 55.11 & 4 & 61.14 & 4 & 44.52 & 4 & 60.00 & 4 \\
\hline
\end{tabular}

viii. External Group

Seven delay causes are listed in the external group. Table 11 shows that the most severe cause from all viewpoints is "Oil price increase". There is no significant difference in the ranking of causes among the viewpoints. There is a wide span of severity index in the combined ranking, ranging from $30.00 \%$ to $64.67 \%$. This indicates that these delay causes have an impact ranging from low to high.

Table 11: Ranking of Delay Causes in External Group

\begin{tabular}{|c|c|c|c|c|c|c|c|c|}
\hline \multirow[b]{2}{*}{ Cause } & \multicolumn{2}{|c|}{$\begin{array}{l}\text { Combined' } \\
\text { view }\end{array}$} & \multicolumn{2}{|c|}{$\begin{array}{l}\text { Contractors' } \\
\text { view }\end{array}$} & \multicolumn{2}{|c|}{ Owners' view } & \multicolumn{2}{|c|}{$\begin{array}{l}\text { Consultants' } \\
\text { view }\end{array}$} \\
\hline & $\begin{array}{c}\text { Severity } \\
\text { index } \\
(\%) \\
\end{array}$ & Rank & $\begin{array}{c}\text { Severity } \\
\text { index } \\
(\%)\end{array}$ & Rank & $\begin{array}{c}\text { Severity } \\
\text { index } \\
(\%)\end{array}$ & Rank & $\begin{array}{c}\text { Severity } \\
\text { index } \\
(\%)\end{array}$ & Rank \\
\hline Oil price increase & 64.67 & 1 & 80.00 & 3 & 55.48 & 1 & 54.17 & 1 \\
\hline Change in loans policy by bank & 64.22 & 2 & 80.57 & 1 & 55.48 & 1 & 51.67 & 2 \\
\hline $\begin{array}{l}\text { Exchange rate fluctuation under } \\
\text { contract }\end{array}$ & 58.44 & 3 & 80.57 & 1 & 44.52 & 4 & 44.17 & 3 \\
\hline Monopoly market & 53.33 & 4 & 78.29 & 4 & 37.42 & 6 & 37.50 & 5 \\
\hline Weather conditions & 46.22 & 5 & 48.57 & 5 & 45.16 & 3 & 44.17 & 3 \\
\hline Public events & 42.22 & 6 & 45.14 & 6 & 42.58 & 5 & 37.50 & 5 \\
\hline Political situation & 30.00 & 7 & 40.57 & 7 & 22.58 & 7 & 24.17 & 7 \\
\hline
\end{tabular}

c) Overall Ranking of Delay Causes

The severity index and ranking of all investigated 53 causes of delay in road construction projects from the four viewpoints are listed in Table 12.

There are two causes with a severity index above $80 \%$ in the combined viewpoint: "Contractor cash flow" and "Delayed payment by owner". There are also three causes with a severity index above $70 \%$ : "Difficulties in financing project by contractor", "Financial issues related to owner" and "Insufficient equipment and vehicles for the work". A discussion on these top five delay causes from combined viewpoint can be made as follows.

\section{- Contractor cash flow}

The issue of contractor cash flow is found to be the top cause of delays in road construction projects in Laos. Many contracting companies in Laos are not only involved in road construction projects, so they have many other activities going on and may have taken on more contracted projects than cash flow can support. As a result, many contractors have put revolving money into other projects. Further, this problem commonly results from the second-ranked cause of delays according to the combined viewpoint: "Delayed payment by owner". Payments may be overdue for a particular project or, in some cases, payments from previously completed projects for the same owner are delayed [16]. These are important causes of "Contractor cash flow".

- Delayed payment by owner

"Delayed payment by owner" is the secondranked cause of project delays. It has a number of causes, including: project cost exceeds original estimate; payments are staged and payment approval is 
slow; lack of clear payment guidelines; and increased project cost because of loan interest. Especially, disaster-recovery projects often cost more than the initial estimate.

Late payment appears to be a critical cause of delays in other countries, such as the West Bank in Palestine [1] (rank 4), Saudi Arabia[17][18] (rank 2 in both studies), Kuwait [19] (rank 2), Malaysia [20] (rank 4), Ghana [3] (rank 1), and Nigeria [21] (rank 2).

\section{- Difficulties in financing project by contractor}

Many contractors have difficulties in financing projects in Laos. This has some connection with the second-ranked cause of delays: "Delayed payment by owner". Also, contractors may be taking on business projects beyond their capability to invest because of insufficient financial resources; they may have poor cash flow management; and most road construction projects in Laos require the contractor to cover the investment required until the project is accepted by the owner (generally the Laos government), after which payment is made according to the contract. The owner usually pays in stages for 3 to 7 years after completion depending on the size of the project and annual budget plan.

- Financial issues related to owner

There are a number of factors relating to the financial status of the owner that can cause problems, such as: approvals of additional projects not included in the original annual master plan; the project has a much higher value than originally estimated; and payment approvals from owner delayed, so interest accrues on project cost. Also, in many cases of disaster-recovery projects, the quantity of work turns out to be higher than originally estimated.

- Insufficient equipment and vehicles for the work

Many road construction projects in Laos have to be carried out using less equipment and vehicles than initially specified in the contract. Further, the quality of equipment and/or vehicles is sometimes inadequate. The causes of this issue may be the insufficient examination of the contract documents. It is not unknown for a contractor to have another ongoing project at the same time and to move some equipment and/or vehicles to that project.

Only three causes have a severity index of less than $40 \%$ in the combined viewpoint, meaning that they have a low impact level: "Personal conflicts among laborers"; "Unclear assignment of responsibility near province boundaries"; and "Political situation".

Table 12: Overall Ranking of Delay Causes

\begin{tabular}{|c|c|c|c|c|c|c|c|c|}
\hline \multirow[b]{2}{*}{ Cause } & \multicolumn{2}{|c|}{ Combined view } & \multicolumn{2}{|c|}{ Contractors' view } & \multicolumn{2}{|c|}{ Owners' view } & \multicolumn{2}{|c|}{ Consultants' view } \\
\hline & $\begin{array}{c}\text { Severity } \\
\text { index } \\
(\%)\end{array}$ & Rank & $\begin{array}{c}\text { Severity } \\
\text { index } \\
(\%)\end{array}$ & Rank & $\begin{array}{c}\text { Severity } \\
\text { index } \\
\text { (\%) }\end{array}$ & Rank & $\begin{array}{c}\text { Severity } \\
\text { index } \\
\text { (\%) }\end{array}$ & Rank \\
\hline Contractor cash flow & 84.22 & 1 & 88.00 & 2 & 78.71 & 1 & 85.83 & 1 \\
\hline Delayed payment by owner & 81.56 & 2 & 91.43 & 1 & 73.55 & 3 & 77.50 & 2 \\
\hline $\begin{array}{l}\text { Difficulties in financing } \\
\text { project by contractor }\end{array}$ & 77.11 & 3 & 82.29 & 4 & 75.48 & 2 & 71.67 & 4 \\
\hline $\begin{array}{c}\text { Financial issues related to } \\
\text { owner }\end{array}$ & 75.11 & 4 & 85.71 & 3 & 68.39 & 4 & 68.33 & 6 \\
\hline $\begin{array}{l}\text { Insufficient equipment and } \\
\text { vehicles for the work }\end{array}$ & 70.89 & 5 & 77.71 & 9 & 61.29 & 5 & 73.33 & 3 \\
\hline $\begin{array}{l}\text { Lack of equipment } \\
\text { efficiency }\end{array}$ & 65.33 & 6 & 74.86 & 12 & 56.77 & 8 & 62.50 & 10 \\
\hline Shortage of equipment & 65.11 & 7 & 75.43 & 11 & 52.26 & 14 & 66.67 & 7 \\
\hline Oil price increase & 64.67 & 8 & 80.00 & 7 & 55.48 & 9 & 54.17 & 17 \\
\hline $\begin{array}{c}\text { Change in loans policy by } \\
\text { bank }\end{array}$ & 64.22 & 9 & 80.57 & 5 & 55.48 & 9 & 51.67 & 21 \\
\hline Insufficient laborers & 63.33 & 10 & 68.57 & 16 & 50.97 & 16 & 71.67 & 4 \\
\hline Poor quality control & 63.11 & 11 & 71.43 & 13 & 54.19 & 11 & 62.50 & 10 \\
\hline $\begin{array}{l}\text { Insufficiently skilled } \\
\text { equipment operator }\end{array}$ & 61.33 & 12 & 68.57 & 16 & 52.90 & 12 & 61.67 & 13 \\
\hline Low project bid price & 60.00 & 13 & 76.57 & 10 & 39.35 & 44 & 62.50 & 10 \\
\hline $\begin{array}{l}\text { Insufficiently skilled } \\
\text { technical staff }\end{array}$ & 59.78 & 14 & 61.14 & 24 & 57.42 & 6 & 60.83 & 14 \\
\hline $\begin{array}{c}\text { Exchange rate fluctuation } \\
\text { under contract }\end{array}$ & 58.44 & 15 & 80.57 & 5 & 44.52 & 30 & 44.17 & 30 \\
\hline Low labor productivity & 58.22 & 16 & 68.00 & 18 & 50.97 & 16 & 53.33 & 19 \\
\hline Shortage in materials & 58.22 & 16 & 61.71 & 22 & 48.39 & 19 & 65.83 & 8 \\
\hline Delayed decision by owner & 57.33 & 18 & 71.43 & 13 & 48.39 & 19 & 48.33 & 27 \\
\hline
\end{tabular}




\begin{tabular}{|c|c|c|c|c|c|c|c|c|}
\hline \\
\hline $\begin{array}{c}\text { Ineffective planning } \\
\text { management by contractor }\end{array}$ & 57.33 & 18 & 52.00 & 32 & 57.42 & 6 & 65.00 & 9 \\
\hline $\begin{array}{l}\text { Improper construction } \\
\text { method }\end{array}$ & 56.00 & 20 & 58.29 & 29 & 49.68 & 18 & 60.83 & 14 \\
\hline $\begin{array}{c}\text { Changes in material types } \\
\text { and specifications during } \\
\text { construction }\end{array}$ & 55.11 & 21 & 61.14 & 24 & 44.52 & 30 & 60.00 & 16 \\
\hline Monopoly market & 53.33 & 22 & 78.29 & 8 & 37.42 & 48 & 37.50 & 45 \\
\hline $\begin{array}{l}\text { Insufficient inspectors } \\
\text { Poor communication }\end{array}$ & 52.00 & 23 & 68.00 & 18 & 43.23 & 34 & 40.00 & 42 \\
\hline $\begin{array}{l}\text { between contractor and } \\
\text { other parties }\end{array}$ & 52.00 & 23 & 49.71 & 37 & 52.90 & 12 & 54.17 & 17 \\
\hline $\begin{array}{l}\text { Change order from owner } \\
\text { during construction }\end{array}$ & 51.33 & 25 & 57.71 & 30 & 45.81 & 25 & 49.17 & 25 \\
\hline $\begin{array}{l}\text { Delay in implementing } \\
\text { inspection by consultant }\end{array}$ & 50.44 & 26 & 70.86 & 15 & 39.35 & 44 & 35.00 & 49 \\
\hline $\begin{array}{l}\text { Coordination between } \\
\text { owner and contractor. }\end{array}$ & 49.78 & 27 & 60.00 & 27 & 43.87 & 33 & 42.50 & 38 \\
\hline $\begin{array}{l}\text { Necessity to re-do work due } \\
\text { to contractor failings }\end{array}$ & 49.78 & 27 & 50.29 & 36 & 46.45 & 24 & 53.33 & 19 \\
\hline $\begin{array}{l}\text { Late issue of approval } \\
\text { documents by owner. }\end{array}$ & 49.56 & 29 & 61.14 & 24 & 40.65 & 39 & 44.17 & 30 \\
\hline $\begin{array}{l}\text { Unreasonable project } \\
\text { timeframe }\end{array}$ & 49.33 & 30 & 50.86 & 34 & 52.26 & 14 & 43.33 & 34 \\
\hline Delayed design work & 48.22 & 31 & 46.29 & 44 & 47.74 & 21 & 51.67 & 21 \\
\hline $\begin{array}{c}\text { Not well-defined scope of } \\
\text { work }\end{array}$ & 48.00 & 32 & 58.86 & 28 & 41.94 & 36 & 40.00 & 42 \\
\hline $\begin{array}{l}\text { Poorly qualified inspector } \\
\text { Poor coordination between }\end{array}$ & 47.78 & 33 & 65.71 & 20 & 38.71 & 46 & 33.33 & 51 \\
\hline $\begin{array}{l}\text { the consultant and } \\
\text { contractor(s) }\end{array}$ & 47.78 & 33 & 61.71 & 22 & 40.65 & 39 & 36.67 & 48 \\
\hline $\begin{array}{c}\text { Delayed land expropriation } \\
\text { by owner }\end{array}$ & 47.11 & 35 & 53.14 & 31 & 40.65 & 39 & 46.67 & 29 \\
\hline $\begin{array}{l}\text { Delayed approval of } \\
\text { materials }\end{array}$ & 46.89 & 36 & 63.43 & 21 & 37.42 & 48 & 35.00 & 49 \\
\hline Poor soil quality & 46.89 & 36 & 43.43 & 50 & 47.10 & 23 & 51.67 & 21 \\
\hline Poor resource management & 46.44 & 38 & 49.71 & 37 & 41.94 & 36 & 47.50 & 28 \\
\hline Weather conditions & 46.22 & 39 & 48.57 & 40 & 45.16 & 28 & 44.17 & 30 \\
\hline Mistakes in design & 46.22 & 39 & 44.57 & 46 & 45.16 & 28 & 50.00 & 24 \\
\hline $\begin{array}{l}\text { Conflict between contractor } \\
\text { and other parties }\end{array}$ & 46.22 & 39 & 42.86 & 51 & 47.74 & 21 & 49.17 & 25 \\
\hline Poor terrain conditions & 46.22 & 39 & 48.00 & 41 & 45.81 & 25 & 44.17 & 30 \\
\hline Poor ground conditions & 45.11 & 43 & 47.43 & 43 & 45.81 & 25 & 40.83 & 40 \\
\hline Inappropriate design & 44.22 & 44 & 44.57 & 46 & 44.52 & 30 & 43.33 & 34 \\
\hline $\begin{array}{l}\text { Inconvenient site access } \\
\text { Personal conflict between }\end{array}$ & 43.78 & 45 & 50.86 & 34 & 40.65 & 39 & 37.50 & 45 \\
\hline $\begin{array}{l}\text { laborers and management } \\
\text { team }\end{array}$ & 43.11 & 46 & 44.00 & 49 & 41.94 & 36 & 43.33 & 34 \\
\hline Construction area restricted & 42.67 & 47 & 49.14 & 39 & 38.71 & 46 & 38.33 & 44 \\
\hline Public events & 42.22 & 48 & 45.14 & 45 & 42.58 & 35 & 37.50 & 45 \\
\hline $\begin{array}{l}\text { Consultant too lenient } \\
\text { Project delayed by owner }\end{array}$ & $\begin{array}{l}41.33 \\
41.33\end{array}$ & $\begin{array}{l}49 \\
49\end{array}$ & $\begin{array}{l}52.00 \\
48.00\end{array}$ & $\begin{array}{l}32 \\
41\end{array}$ & $\begin{array}{l}40.65 \\
32.90\end{array}$ & $\begin{array}{l}39 \\
51\end{array}$ & $\begin{array}{l}26.67 \\
42.50\end{array}$ & $\begin{array}{l}52 \\
38\end{array}$ \\
\hline $\begin{array}{l}\text { Personal conflict among } \\
\text { laborers }\end{array}$ & 39.78 & 51 & 40.00 & 53 & 36.77 & 50 & 43.33 & 34 \\
\hline $\begin{array}{l}\text { Unclear assignment of } \\
\text { responsibility near province } \\
\text { boundaries }\end{array}$ & 38.00 & 52 & 44.57 & 46 & 28.39 & 52 & 40.83 & 40 \\
\hline Political situation & 30.00 & 53 & 40.57 & 52 & 22.58 & 53 & 24.17 & 53 \\
\hline
\end{tabular}


d) Top Five Causes of Delay from each viewpoint

The top five delay causes from each viewpoint are picked up from Table 12 and listed in Tables 13-15 with their related groups. They are similar, and three causes, "Delayed payment by owner", "Contractor cash flow" and "Difficulties in financing project by contractor", are included in all tables. "Insufficient equipment and vehicles for the work" is included in the tables from owners' and consultants' viewpoint, indicating that there is only one cause different between them. It can be said that the recognition of the important causes of project delay is basically shared among contractors, owners and consultants. However, the level of the severity evaluated by contractors, owners and consultants is different. Severity indexes from the contractors' viewpoint are considerably higher than from the owners' and consultants' viewpoint. This fact can be also recognized from Table 12.

Table 13: Top Five Delay Causes and Related Groups from Contractors' Viewpoint

\begin{tabular}{cccc}
\hline Cause & $\begin{array}{c}\text { Related } \\
\text { group }\end{array}$ & $\begin{array}{c}\text { Severity } \\
\text { index } \\
(\%)\end{array}$ & Rank \\
\hline Delayed payment by owner & Owner & 91.43 & 1 \\
Contractor cash flow & Contractor & 88.00 & 2 \\
Financial issues related to owner & Owner & 85.71 & 3 \\
Difficulties in financing project by & Contractor & 82.29 & 4 \\
contractor & External & 80.57 & 5 \\
\hline
\end{tabular}

Table 14: Top Five Delay Causes and Related Groups from Owners' Viewpoint

\begin{tabular}{|c|c|c|c|}
\hline Cause & $\begin{array}{l}\text { Related } \\
\text { group }\end{array}$ & $\begin{array}{l}\text { Severity } \\
\text { index } \\
(\%)\end{array}$ & Rank \\
\hline \multirow{2}{*}{$\begin{array}{c}\text { Contractor cash flow } \\
\text { Difficulties in financing project by } \\
\text { contractor }\end{array}$} & Contractor & 78.71 & 1 \\
\hline & Contractor & 75.48 & 2 \\
\hline \multirow{3}{*}{$\begin{array}{l}\text { Delayed payment by owner } \\
\text { Financial issues related to owner } \\
\text { Insufficient equipment and vehicles for } \\
\text { the work }\end{array}$} & Owner & 73.55 & 3 \\
\hline & Owner & 68.39 & 4 \\
\hline & Contractor & 61.29 & 5 \\
\hline
\end{tabular}

Table 15: Top Five Delay Causes and Related Groups from Consultants' Viewpoint

\begin{tabular}{cccc}
\hline Cause & $\begin{array}{c}\text { Related } \\
\text { group }\end{array}$ & $\begin{array}{c}\text { Severity } \\
\text { index } \\
(\%)\end{array}$ & Rank \\
\hline $\begin{array}{c}\text { Contractor cash flow } \\
\text { Delayed payment by owner }\end{array}$ & Contractor & 85.83 & 1 \\
Insufficient equipment and vehicles for & Owner & 77.50 & 2 \\
$\begin{array}{c}\text { the work } \\
\text { Difficulties in financing project by } \\
\text { contractor } \\
\text { Insufficient laborers }\end{array}$ & Contractor & 73.33 & 3 \\
& Contractor & 71.67 & 4 \\
\hline
\end{tabular}

\section{e) Ranking of Groups}

For this study, the causes of delay were classified into eight groups as described above. Here, these groups are ranked according to the grouped severity index of their causes as determined by contractors, owners, consultants. The results are presented in Table 16.

From the combined viewpoint, the three top groups are: Materials and equipment; Contractor; and Laborers. The range of severity index is narrow, from $46.22 \%$ to $60.94 \%$. The top three groups from the contractors' viewpoint are: Materials and equipment; External; and Consultant. Those from owners' and consultants' viewpoint are the same: Contractor; Materials and equipment; and Laborers. The group with the lowest severity index is the Project group from contractors' viewpoint, and the Consultant group from owners' and consultants' viewpoint. Again, the group ranking from owners' and consultants' viewpoint is quite similar. 
Table 16: Group Ranking

\begin{tabular}{|c|c|c|c|c|c|c|c|c|}
\hline \multirow[b]{2}{*}{ Group } & \multicolumn{2}{|c|}{ Combined view } & \multicolumn{2}{|c|}{$\begin{array}{c}\text { Contractors' } \\
\text { view }\end{array}$} & \multicolumn{2}{|c|}{ Owners' view } & \multicolumn{2}{|c|}{$\begin{array}{c}\text { Consultants' } \\
\text { view }\end{array}$} \\
\hline & $\begin{array}{c}\text { Severity } \\
\text { index } \\
(\%)\end{array}$ & Rank & $\begin{array}{c}\text { Severity } \\
\text { index } \\
(\%)\end{array}$ & Rank & $\begin{array}{c}\text { Severity } \\
\text { index } \\
(\%)\end{array}$ & Rank & $\begin{array}{c}\text { Severity } \\
\text { index } \\
(\%)\end{array}$ & Rank \\
\hline Materials and equipment & 60.94 & 1 & 68.29 & 1 & 50.48 & 2 & 63.75 & 1 \\
\hline Contractor & 60.26 & 2 & 62.13 & 5 & 56.66 & 1 & 60.26 & 2 \\
\hline Laborers & 53.16 & 3 & 57.83 & 6 & 46.71 & 3 & 53.16 & 3 \\
\hline Owner & 52.94 & 4 & 62.19 & 4 & 46.18 & 4 & 48.19 & 5 \\
\hline External & 51.30 & 5 & 64.82 & 2 & 43.32 & 6 & 41.90 & 7 \\
\hline Consultant & 47.87 & 6 & 63.66 & 3 & 40.52 & 8 & 34.33 & 8 \\
\hline Project & 47.44 & 7 & 45.06 & 8 & 42.90 & 7 & 45.83 & 6 \\
\hline Design & 46.22 & 8 & 45.14 & 7 & 45.81 & 5 & 48.33 & 4 \\
\hline
\end{tabular}

f) Severity rank correlation

The Spearman rank correlation is used to measure the correspondence between contractors' and owners' responses, contractors' and consultants' responses, and owners' and consultants' responses. Equation (3) is used for this purpose. There is relatively good agreement (positive correlation) between contractors' and owners' rankings of delay causes, with rs $=+0.474$. There is also good agreement between contractors and consultants, with $r s=+0.465$. Between owners and consultants, the correlation is $r s=+0.831$, which is a very good relative agreement between the two parties in the ranking of delay causes. This may be because the consultant is usually the agents acting owners' behalf.

\section{Recommendations to Reduce delays in Road Construction Projects IN LAOS}

The following recommendations are made to all parties as ways to reduce and control delays in road construction projects:

The project owner, meaning the Laos government, should pay special attention to the following points:

- Making the required decisions on time so as to improve communications and coordination with other construction parties (donors, consultants and contractors).

- Making efforts to modify and improve regulations, contracts and laws related to road projects to address the causes of delay shown to have a high severity index.

- Implementing annual programs for continuous training in cooperation with the contractor's union as a way to improve managerial skills, the checking and repair of equipment and vehicles, site engineering ability and labor skills.

- Resolving the problem of delayed payments to ensure that staged payments are made to contractors on time, since late payments affect a contractor's ability to finance the work. The result is time overruns and contracting companies may also use late payments as a reason to bargain with the Laos government (owner) in the case of delay.

- Allowing sufficient time to make adequate preparations for a project. This includes drawing up a planning schedule, particularly for the design phase to avoid the need for changes; detailed and comprehensive investigations of the site and site environment; and fully documenting all information before finally submitting the tender. This will help to avoid and later errors and thereby help avoid or minimize time and/or cost overruns.

- Re-checking the background, capabilities and resources of contracting companies before awarding the contract to the lowest bidder.

Contractors should consider the following:

- Ensuring the availability of sufficient resources in terms of budget, engineers, staff, laborers, equipment, vehicles and others that are necessary before bidding and making efforts to carry out projects at the specified time.

- Improving management of financial resources and cash flow by requesting staged payments.

- Ensuring that sufficiently skilled managers, engineers and staff are involved in the project.

- Providing expert training for laborers in relevant work practices so as to improve skills before beginning work, especially in the case of large projects or high-risk workplaces.

- Taking responsibility for the specified quality, cost and schedule.

- Improving communications and coordination with other construction parties (donors, owners, consultants and others) so as to obtain good results.

Consultants should look to the following:

- Providing all necessary information and documentation for the road construction project to other construction parties and, if possible, preparing sample documents and a recommended timeline for document processing. 
- Providing owners and contractors with payment documents in a more timely way, because the severity index of "contractor revolving money" and "owner payment is postponing" are the top of causes of delays in road construction projects.

\section{Conclusion}

In this study, the causes of these delays are elucidated through a questionnaire survey, with the severity of each cause obtained from the viewpoints of contractors, owners and consultants. The 53 possible causes of delay included in the questionnaire were obtained through a detailed literature review and in consultation with expert civil engineers in Laos. The identified causes are combined into eight groups: project, owner, contractor, consultant, design, laborers, materials and equipment and external. The questionnaire was completed by 35 contractors, 31 owners and 24 consultants.

The top five causes of delay by severity index in the ranking obtained from the results are the following:

- Contractor cash flow;

- Delayed payment by owner;

- Difficulties in financing project by contractor;

- Financial issues related to owner; and

- Insufficient equipment and vehicles for the work.

The Spearman rank correlation showed that there is relatively good overall agreement between contractors and owners ( $r s=+0.474)$, contractors and consultants ( $r s=+0.465)$ and especially between owners and consultants ( $r s=+0.831$ ) as to the severity rank of delay causes.

Further analysis of the data obtained from the questionnaire showed the following:

- There are no causes of delay with a severity index less than $20 \%$;

- Severity indexes from the contractors' viewpoint are considerably higher than from the owners' and consultants' viewpoint. There are no causes with a severity index of less than $40 \%$ from the contractors' viewpoint; and

- The group severity index from the combined viewpoint ranges between $46.22 \%$ and $60.94 \%$. This indicates that all the identified causes are highly relevant to the problem of delays in road construction projects in Laos.

The results of this study suggest that a necessary future task is to use the severity index of delay causes as a baseline for improving rules, agreements, management, administration and planning. The modified processes should be tested and used, then checked against percentage delays to determine if there has been any improvement. This process should be iterated to make the project implementation process as good as possible.

\section{References Références Referencias}

1. Ibrahim Mahamid; Amund Bruland; and Nabil Dmaidi. Causes of Delay in Road Construction Projects. Journal of Management in Engineering, 2012, 28: 300-310.

2. Odeh, A.M.; Battaineh, H.T. Causes of construction delay: Traditional contracts. International Journal of Project Management. 2002, 20: 67-73.

3. Frimpong, Y.; Oluwoye, J.; Crawford, L. Causes of delay and cost overruns in construction of groundwater projects in a developing countries; Ghana as a case study. International Journal of Project Management 2003, 21: 321-326.

4. J.A. Alsuliman. Causes of delay in Saudi public construction Projects. Alexandria Engineering Journal; 2019, 58: 801-808.

5. E.T. Banobi and W. Jung. Causes and Mitigation Strategies of Delay in Power Construction Projects: Gaps between Owners and Contractors in Successful and Unsuccessful Projects. Sustainability 2019, 11: 5973.

6. R.F. Aziz, A.A. Abdel-Hakam. Exploring delay causes of road construction projects in Egypt. Alexandria Engineering Journal; 2016, 55: 15151539.

7. Khatib, B.A.; Poh, Y.S.; El-Shafie, A. Delay Factors in Reconstruction Projects: A Case Study of Mataf Expansion Project. Sustainability 2018, 10: 4772.

8. Orangi, E. Palaneeswaran, J. Wilson. Exploring Delays in Victoria-Based Australian Pipeline Projects. Procedia Engineering; 2011, 14: 874-881.

9. M.H. Fallahnejad. Delay causes in Iran gas pipeline projects. International Journal of Project Management; 2013, 31: 136-146.

10. Majed Alzara, Jacob Kashiwagi, Dean Kashiwagi, Abdulrahman Al-Tassan. Using PIPS to minimize causes of delay in Saudi Arabian construction projects: university case study. Procedia Engineering; $2016,145: 932$ - 939.

11. B.-G. Hwang, Xianbo Zhao, Si Yi Ng. Identifying the critical factors affecting schedule performance of public housing projects. Habitat International; 2013, 38: 214-221.

12. Raj Kapur Shah, An Exploration of Causes for Delay and Cost Overruns in Construction Projects: Case Study of Australia, Malaysia \& Ghana, Journal of Advanced College of Engineering and Management, 2016, Vol. 2

13. Long, N.D.; Ogunlana, S.; Quang, T.; Lam, K.C. Large construction projects in developing countries: A case study from Vietnam. Int. J. Proj. Manag. 2004, 22: 553-561.

14. Michał Głuszak and Agnieszka Leśniak. Construction delays in clients opinion - multivariate statistical analysis. Procedia Engineering; 2015, 123: $182-189$. 
15. Ogunlana, S.O.; Promkuntong, K.; Jearkjirm, V. Construction delays in a fast-growing economy: Comparing Thailand with other economics. Int. J. Proj. Manag. 1996, 14: 37-45.

16. Refer to the letter of Ministry of Public Works and Transport No.538/MPWT, Dated 31 May 2019. Page 2.2-3. (http://www.mpwt.gov.la/attachments/article/ 1994/00538-MPWT,\%20Hotline\%20Govt\%20to\%20 MPWT.pdf).

17. Al-Khalil, M., Assaf, S., and Al-Hazmi, M.. Causes of delays in large building construction projects, Journal of Management in. Engineering, 1995, 11(2): 45-50

18. Assaf, S. A., and Al-Hejji, S.. Causes of delay in large construction projects, International Journal of Project Management, 2006, 24(4): 349-357.

19. Koushki, P., Al-Rashid, K., and Kartam, N.. Delays and cost increases in construction of private residential projects in Kuwait, Constr. Manage. Econ. 2005, 23(3): 285-294.

20. Sambasivan, M., and Soon, Y.W.. Causes and effects of delays in Malaysian construction industry, International Journal of Project Management, 2007, 25(5): 517-526

21. Aibinu, A. A., and Jagboro, G. O.. The effects of construction delays on project delivery in Nigerian construction industry, International Journal of Project Management, 2002, 20(8): 593-599. 